\title{
A Review of Customer Satisfaction Factors in Libyan Housing Projects
}

\author{
Abdulhamid Shebob ${ }^{1}$, Raj Shah ${ }^{2}$, and Amit Mhalas ${ }^{3}$ \\ Received April 10, 2013 / Revised May 14, 2013 / Accepted June 19, 2013
}

\begin{abstract}
Customer satisfaction and customer relationship are crucial aspect in any enterprises including housing construction projects. In general, the housing developers are facing a number of new challenges in different countries including Libya. The construction industries/housing developers need to continuously improve their products and services to meet customers' satisfaction desires and to remain in the current competitive market. This paper focuses on analysing the satisfaction factors of customers including qualityaspects of products and services in the construction projects. A framework was developed to evaluate the dynamics relationship between customer satisfaction and quality products or services, aiming to help companies' managers and policy makers to understand the needs and points of view of their customers. Apragmatic analysis was conducted to explore and analyse the customer satisfaction factors in construction industry considering different aspect of customer groups in Libya. Results indicate that there is a high demand of improvements in the contractor's performance in terms of cost, time and quality of products. It was also found that Libyan construction companies have been forced to transform their policies after on Libyan war 2011 to focus on client and customer satisfactory policies, or say centric for the purpose of improving client requirements and turn the business into more advantageous for any company.
\end{abstract}

Keywords: Customer Satisfaction Factors, Housing Project, Customer Relationship

\section{INTRODUCTION}

The customer satisfaction and customer relationship are crucial factors, which are interrelated in building construction projects. Generally, project manager in the building industry must have concern about the client liking due to estimated future control on projects and the reputations of organization (Karna, 2004).Customer normally measure the efficiency of delivery goods or services by their set presentation standards, Clients mostly pleased while their apparent presentation are upper than the principals "surely not confirmed", dissatisfaction while performance occur below than expected standard (Karna, 2004). For any companies to become more competitive at market directly depends on the client satisfaction in terms of quality and reliability of goods or services. Customer satisfaction either can be treating as an aim of or a capacity instrument for the improvement of building quality, profitability and remain in competitiveness in market (Anderson and Sullivan, 1993).

Many authors in construction significance emphasis on client liking and its employ for assessing be eligible from client point of views (Torbica and Stroh, 2001; Maloney, 2002; Yasamiset al, 2002).Last few years though some key changes have been occurred in the residence construction area, generally due to increasing competitions and boosting need for superiority through clients (Formoso and Jobim, 2006). Since 1998, Hong Kong housing marketing went through a number of structural changes; now building developers more concerned with making worth of houses (Shen and Dong, 2000). In Japanese big residence sector, construction companies transformed significantly by adopting base techniques those used in some housing builders (Gann, 1996). Some initiative had been taken in the USA for the purpose of enhance the functions of construction housing like as the Partnership for using latest expertise in accommodation and the Manufactured Housing Alliance (MHRA).

Customer satisfaction has become one of the key issues for companies in their efforts to improve quality in the competitive marketplace. It can be seen as either a goal of or a measurement tool in the development of construction quality. The objective of this paper is to examine and deepen the understanding of customer satisfaction factors in the construction projects, particularly in Libya. The following sections discuss these efforts with a literature review, framework was developed, and subsequently the results of an empirical study are presented. Finally a discussion and implications of the findings are presented.

\section{LITERATURE REVIEW}

Customer satisfaction is a complex concept. Past researchers have argued that there is a distinction between

\footnotetext{
${ }^{1}$ Research assistant, School of Science and Engineering (SSE), Teesside University, Middlesbrough, UK, Tel/Fax: +44 1642 342494 ,

A.Shebob@tees.ac.uk (*Corresponding Author)

${ }^{2}$ Senior Lecturer, Built Environment, Liverpool John Moores University, Liverpool, UK, r.shah@1jmu.ac.uk

${ }^{3}$ PhD Student, Technology Futures Institute, Teesside University, Middlesbrough, UK, a.mhalas@tees.ac.uk
} 
customer satisfaction in respect to tangible products and services (Besterfield, 1994; Barsky, 1995; Kanji and Moura, 2002; Fecikova, 2004). This distinction is due to the inherent intangibility and perishability of services, as well as the inability to separate production and consumption. Hence, customer satisfaction with services and with goods may derive from, and may be influenced by, different factors and therefore should be treated as separately and distinctly. Love et al (2000) suggested that the creation of value between customer and supplier in the construction supply chain industry is the fundamental factor in successful projects.

Macintosh (2007) highlighted that the importance of considering interpersonal level $\mathrm{v}$ and firm level variables in assessing marketing relationships. While it may be argued that service organizations' are interested in promoting strong relationships between customers and the firm, firms cannot ignore the fact that a potentially stronger relationship can be established at the interpersonal level with the contact service employee. Similarly, in most cases one would expect that quality of the interpersonal relationship would be consistent with the customer's assessment of the firm. According to Karna (2009), customer satisfaction can be improved by removing the factors having a negative effect on customer satisfaction. In the management of a construction business, mere routine and technical competence are not enough but alongside technical competence, cooperational skills and the importance of communication and information flow are highlighted. A functioning communication system is a significant precondition for the operations of a work site organization and in building customer satisfaction. The importance of communication is further stressed by the fact that business is based more and more on long-term customer relations. Therefore, the contractor and the builder have to interact in developing their own activities

Customer satisfaction is one of the key elements in total quality management (TQM), an approach that emphasizes overall satisfaction through the continuous improvement of products. Construction companies are adopting TQM to improve their performance. However, construction has lagged behind other industries in implementing total quality management because of its inability to accurately determine customer requirements and successfully transform these requirements into the completed facility (Ahmed and Kangari, 1995). In addition, there is much dissimilarity between manufacturing and construction, so TQM techniques must be adapted for the construction industry. Understanding the customer's requirements is essential in ensuring customer satisfaction, and the demand for the construction product must be viewed in relation to the intended use of the facility. Ahmedand Kangari (1995) suggest that customer orientation, communication skills and response to complaints all play an important role in the overall satisfaction of the customer in the construction industry.

Customer satisfaction can be used for evaluation of quality and ultimately for assessment of the success of a company's quality improvement programmer. According to Torbica and Stroh (2001), a quality improvement effort will lead to a higher product and service quality, which will lead to improved customer satisfaction. Their study has confirmed that implementation of TQM is positively associated with homebuyer satisfaction, and it is the "total offering" that generates the total degree of customer satisfaction. Al-Momani (2000) examined service quality in construction delivered by contractors and the project owner's expectations using the service quality gap as his analysis tool. He found that contractors pay very little attention to the owners (customers) satisfaction, and that this contributes to poor performance.

Barrett (2000) sees that quality in construction can be thought of as the satisfaction of a whole range of performance criteria held by an interacting host of stakeholders and mediated by a range of mechanisms. According to Winch et al(1998) the problem with the existing literature on construction is that it concentrates on the problems of producers instead of providing value for the customer. There is a need for customer orientation and satisfaction, not for allocating liability. Torbica and Stroh (2001) put emphasize that the use of flexible presentation method, like as client liking, is at an start or revolution phase in manufacture of housing in Libya, in other side major spotlight had been on client liking or apply customers satisfaction policy in the manufacturing of housing sector , there importance of client liking and their utilization for measuring the excellence from the client perspectives, had been emphasized by number of authors in building business (Barret 2000; Torbica and Stroh 2001; Maloney, 2002; and Yasamis et al, 2002).

Furthermore, there are a wide variation among the loyalty of simply pleased customer and those who are completely pleased. Those clients who are immediately satisfy found simple to change supplier when a good deal offer from other parties. As an affect their importance of client liking has been emphasize in market where rivalry is strong (Kotler, 2000; Jones and Sasser, 1995).

From the research each service meeting provides an opportunity for the contractor to support its commitment to customer satisfaction or quality. The customer's assessment of each meeting will clearly not be perfectly linked to the customer's whole satisfaction with the contractor or insights of the contractor's quality. However, over time it is likely that many positive (negative) meetings will lead to an overall high (low) level of satisfaction. Thus, customer satisfaction must be considered at both the micro and macro levels. Service meeting satisfaction is the customer's satisfaction or dissatisfaction with an exact service meeting. This reproduces the customer's feelings about the specific meeting and results from the customer's assessments of the events and performances that happen during the meeting. Overall service satisfaction is the customer's overall satisfaction or dissatisfaction with the organization established on all meetings and experiences with that specific organization. It reflects satisfaction or dissatisfaction with a number of kinds of encounters, 
meetings with staffs, negotiations, delivery, and postcontract award services within the same company. Customers will differentiate their satisfaction with a specific meeting from their overall satisfaction with the company services.

In addition to satisfaction, a problem of major worry to the customer is service quality, which may be clear as the customer's overall impression of the relative inferiority or superiority of the organization and its services. Most customers want higher service quality, but at the same time they want the lowest price. The combination of service quality and the price paid for that quality is the value received by the customer. Satisfaction can be viewed in terms of a process of "expectancy disconfirmation," in which satisfaction is based largely on meeting or exceeding expectations.

\section{A. Factors affecting customer satisfaction}

Karna (2009) found that the important matter in selecting the factors was examining them on the level of concepts and contents, i.e., how well they describe the various factors of construction. With the help of factor analysis, the study showed the kinds of hidden, latent factors described by the variables. As a result of the factor analysis, the original 22 variables formed into 10 structurally meaningful factors which were then interpreted. The final conclusion was that a solution with ten factors would be ideal. This was due to the fact that over-simplification as a result of decreasing the number of factors was to be avoided as then essential matters could be omitted from examination. On the other hand, the number of factors should be significantly lower than the original 22 variables.

The Ireland (1992) lists the possible clients those have expectation and requirement which affects the productivity of a project. It is a thorough perspective on the customer consists of: the co-contractor and partner, plan executive, development group member, service provider and subcontractor, salesperson and supplier, user of the goods and facility and community. This is also crucial to remind that there are normally various people involve in a purchasing decision. The purchasing center consist of all persons those involve in the purchasing of the services and consist of the below deciders, influences, purchasers, doorkeeper and users. Client liking are affected through the role of individuals member of the buyer center in term of interest and goal, the judgment procedure and structure (Brockmann, 2002).

It is multifaceted kind of the building processes; alterations in project organization and the individuality of every venture make it hard to learn from past experience and client feedbacks in upcoming task. Furthermore, Love et al(2000) recommend that every continuous in the building provide chains either customers and suppliers those are creation of value is the fundamental factor for success of project. Customer satisfaction need to be view and understand as an affiliation particularly rather than contract precise constructs. According to Homburgh and Rudolph (2001), the conventional relationships administration model employed in the manufacture but not in construction where the top product is vital in building.

Holt et al (1995) identified that time; cost and quality are the basic requirements for client satisfaction as well as the parameters for contractor selection. Kometaet al (1994) recognized four vital clients, needs in the built environment, which are Functionality, Safety, Quality, and Completion Time. Chinyo et al (1998) assert that a comprehensive analysis of clients, needs would facilitate greater clients, satisfaction. Here, 34 clients, needs grouped into eight main classes of needs: Aesthetics, Economy, Functionality, Quality, Working Relationships, Safety, Surprises (i.e. lack of :) and Time was identified. The authors further ranked the clients, needs into 50 aspects. Their study conducted on 42 clients in the construction industry identified, project/ work to be built to its intended purpose, as the clients, most important need. Egemen and Mohamed (2006) specifically identified 18 satisfaction needs of clients from contractors. The authors ranked these needs to indicate their level of importance to the clients, as well as serve as a point of focus for the contractors. With respect to the project manager as a participant in construction projects, Chinyoet al (1998) elucidates five factors for creating satisfaction for the project manager. These are personnel, material flow, schedule adherence, contractor, organization and information flow. The next section discusses the a conceptual of framework

\section{FRAMEWORK}

The customer satisfactions can production a dominant function in the assessments of service provider performances. Client contentment in the building manufacturing can be explained as important role a contractor fulfills the client expectation ant the excellence on manufacture project can be accounted as the fulfillment of expectation (Barrett, 2000). The client expectation of manufacture is an occupation of number of factor: the client history or straight knowledge with the contractors, committed, information regarding the service provider and the customer's own requirement. Furthermore client prospects are precious through an outworker advertising performance and representation and the client own asset in the task and the connection.

The customers are also effect through what kind of facility assumed to him and what are he looking for the immediate manufacturing and utilization process. practical merits, though, cannot be evaluate as impartially as the scientific measurement, yet practical qualities would possibly be more crucial than technical quality in evaluating whole apparent excellence. Different services have the character of together excellence measurement (technical; what? and applied; how?). For example, if faults are in the building procedure is stable with reasonable effect for the customer. The result of the imperfection handling process has excellent practical, while if the faults management procedure have to be complicated and it has long time influence. The practical qualities and whole professed qualities maybe are lesser than previous. Therefore, in direct to evaluate the 
activeness of customer contentment and advantage in construction, a structure must be created. The hypothetical foundation for a structure for this present research paper not built through use of the literatures and the characteristic of building quality.

\section{A. Framework design}

In order to assess the customer satisfaction and quality in construction, a conceptual framework is required. A framework of customer relationship and quality was designed using the literature review and the characteristics of construction quality. Basically, the construction is a service industry. Customers purchase the capacity to produce, and typically contribute in the construction development to a considerable level. These are also characteristics of services (Winch et al, 1998).Figure 1 present a conceptual framework of inter relationships between customer satisfaction and quality at project level.

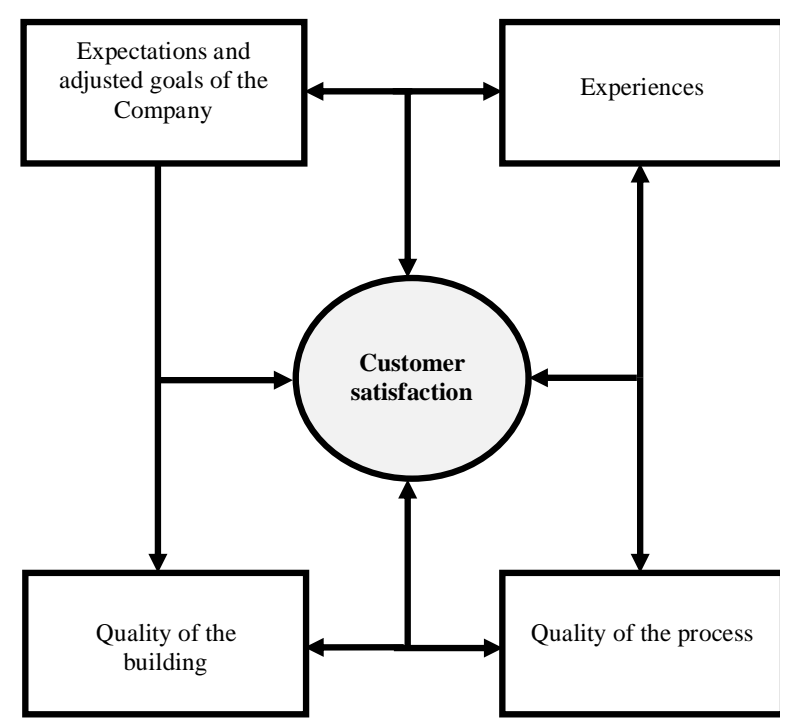

FIGURE I

FRAMEWORK OF INTERRELATIONSHIPS BETWEEN CUSTOMER SATISFACTION AND QUALITY OF PRODUCT

The framework was designed into four categories such as an aims of the company, quality of the building, and quality of the process and experiences. Customers can often measure the connection between customer satisfaction and quality because of its technical environment and how he accepts the service and how he skills the simultaneous production and consumption process. Practical quality, however, cannot be evaluated as objectively as the technical dimension, yet practical quality would maybe more significant than technical quality in defining overall perceived quality. Many services have the environment of both quality dimensions (technical; what? and applied; how?). Instance, if a defect in the construction process is settled with satisfactory results for the customer, the result of the defect handling process has good technical quality, while if the defect handling process had been complicated and time- consuming, the functional quality and total perceived quality would be lower than expected.

The customer's outlooks of construction are a function of several factors as shows in appendix (A, B, C and D). The customer's experiences with the contractor, word-ofmouth information about the contractor and the customer's personal needs are a key aspects considered. In addition, a customer's expectations are affected by a contractor's marketing activities and image, and the customer's own investment in the project and the relationship. The customers' outlooks show a main role in the evaluation of contractor's performance. Customer satisfaction in the construction industry can be defined as how well a contractor meets the customer's outlooks, and the quality on construction projects can be viewed as the satisfaction of outlooks. The next section discusses a case study to evaluate the functions of the framework of interrelationships between customer satisfaction and quality at project level

\section{RESEARCH METHODOLOGY}

According to Wael et al (2007), literature analysis was conducted in order to obtain information about customer satisfaction in a marketing context and in the project business environment. Cluster analysis was used to identify customer satisfaction factors and the level of customer satisfaction. The level of customer satisfaction in the different project types and customer groups was studied by using cross tabulation. Cluster analysis and cross tabulation bring information about the level of customer satisfaction and classification information from the different projects assessed by the customer. A questionnaire is one of the most cost effective ways to collect and analyze a large number of responses from the involved parties in the construction industry in order to achieve better statistical analysis of the data. The aim of the structural equation modelling SME (Small Medium Enterprise) is to explore causal relationships between customer satisfaction factors. Structural equation modelling and factor analysis are used widely on the customer satisfaction context. Recently, SEM modelling has been used for supply chain quality management (Lin et al, 2005), B-to-B satisfaction (Molinari et al, 2008), and customer orientation (Macintosh 2007).

In this study, factors motivating (influencing) customer satisfaction were identified that mainly focus on how the customer satisfied with the facility and how to get valuable learning from past experience. The concurrent manufacture and customer liking in the building manufacturing are described to achieve the customer outlook and the excellence on building projects. The customer history or straight experiences with the contractors and comparable contractors, word-of-mouth data concerning the service provider, and the customer individual desires are considered in the study. In adding, a customer prospect is affected by a service provider advertising behavior and picture and the customer possess deal in the development and the association. Based on these findings, a study tool in the form of a survey was envisioned for use this learning (Ball, 1997; Barlow, 
1998).

\section{A. Questionnaire design}

A questionnaire was designed by analyzing the existing questions, which were used in previous study for identification the factors affecting the customer satisfaction in Libyan housing industry. The questionnaire was divided into two parts, were designed to obtain information regarding customer satisfaction from Libyan building experts was administered. The researcher adopted a scale of 1 (strongly disagree) to 4 (strongly agree) to access the factors from every respondent's opinion on customer satisfaction to several listed factors. The study focused on a specific category of experts in the building industry in Libya; from architects, through engineers to other experts in building industry.

Part one was related to general information of the respondent's experience and associated company. Part two was related to the made up of 4 sub-sections; Section one offered 6 factors about the expectations and adjusted goals of the company which the respondent was asked to rank the effects on customer satisfaction. Section two offered 24 factors about the quality of the building, which may affect customer satisfaction while section three offered 15 factors regarding to quality of the process, and section four offered 10 factors about the contractor experiences.

\section{B. Data collection}

The bias in sampling of public building was selected for data collection as representation of the building companies in Libya. Questionnaires were targeted to respondents, years of working experience, type of company working for and expertise in the building industry by. A total of 60 questionnaires were distributed to respondents in Libya. A total of (43) out of 60 responses $(56.6 \%)$ were received. The questionnaires were collected back via the email. The data had been subject to descriptive analysis for calculation the distribution frequencies of the respondent bio-data. The Likert scales of one to four had been chosen for every factor considered for this survey, various ranking scales been used like $4=$ for strongly agreed, $3=$ for agreed, 2 $=$ for disagreed and $1=$ for strongly disagreed respectively.

\section{Statistical analysis of data}

Collected data was analyzed using SPSS to identify the relationship and confidence level of survey data. The data from Part one of the questionnaire (bio-data of respondents) was subjected to descriptive statistics, to calculate the percentage (\%) of respondents with regards to professional experience group they belong to (from 20years to above 60years)(engineering consultant, architectural consultant, quantity/land surveyors or other categories), type of building company working for (Private, public).

To identify differences among respondent's experiences, education and qualifications in construction, an analysis of variance (ANOVA) was undertaken at the 5 per cent significance level. The results show that there were significant statistical differences in the respondents (the $\mathrm{F}$ ratio is 30.5 and the observed significance level is 0.000). This suggests that the key actors in the Libyan construction industry vary significantly owing to differences in their responsibilities and roles in the construction projects. In short, it can be said that the Libyan construction industry is generally led by educated managers or actors and difference between consultants, contractors and clients in terms of stability in their firms (the $\mathrm{F}$ ratio is 14.33 and the observed significance level is 0.000). However, a significant proportion of staff qualifications are irrelevant to construction and customer satisfaction

The ranking analysis methods suggested by Assaf and Al-Hejji (2006) such Frequency Index (FI) and Importance Weight (IW) was used to analyses the survey data and discuss the survey results. Frequency index method was selected for the ranking of effects on customer satisfaction considering the frequency of occurrence identified by participants in the survey.

$$
(F . I .)(\%)=\sum_{a=1}^{4} a \times\left(\frac{n}{N}\right) \times \frac{100}{4}
$$

Where, a is the constant expressing weighting given to each response (ranges from 1 for strongly disagreed up to 4 for strongly agreed), $\mathrm{n}$ is the frequency of the responses, and $\mathrm{N}$ is total number of responses.

$I W=\frac{[F \cdot I \cdot(\%)]}{100}$

The ranking results are presented in Appendix-A. The appendix shows the Importance Weight (IW) of each effect on customer satisfaction on frequency scale.

\section{SURVEY FINDINGS}

This section discusses the survey data analysis. First, the result of the 4 -point Likert of Importance Weight (IW scale and the calculated (IW)scores based on respondents assessments of the various factors considered to influence customer satisfaction in building construction.

The ranking results are presented in Appendix-A. The appendix shows the 'Importance Weight (IW)of each factor considered by respondents of the (Expectations and adjusted goals of the Company). The most five important (about the company goals in building construction, as follows;

1. Delivered a construction projects on time, within budget and at quality.

2. The company's previous reputation and building project records

3. Possession of the right tools and equipment in desired quantity and quality by the company.

4. Appointment of a competent Project manager and also a support management team.

Availability or procurement of the right materials of 
high quality and in the required quantity.

The above factors which score very high based on the rating of respondents are qualities directly related to the company, its previous construction records, its tender procedures, time it takes to handle projects, ability to appoint competent project manager and support staff, the availability of the right construction tools and equipment by the company and the availability of the right materials of high quality and in the required quantity. In other words, the confidence which a building construction company has built in its customers over the years of its operation, in terms of quality of service, completion of project within budget and at specified time and the competence of its employees assist to a large extent in ensuring customer satisfaction.

Second, the result of the 4-point Likert scale scores and the calculated 'Importance Weight (IW)scores based on respondents assessments of the various factors considered to influence customer satisfaction (Quality of the building).From the cross-comparison of the calculated IW scores presented in Appendix-B, the most important factors considered by respondents to affects customer satisfaction (Quality of the building construction), in relative order most important in each sub-section in the performance of building as a whole were external appearance of the building, safety of the building (protection against crime) and location of the building. Whereas the performance of the apartment were the adequacy of space to furniture and to programmed activities, natural conditions of comfort, electrical services, water service and quality of the finishing

The analysis of factors above which score very high in relative importance compared to the others shows that these are attributes which are directly related to the preferences of the customer satisfaction.

Thirdly, the result of the 4-point Likert scale scores and the calculated Importance Weight (IW) scores based on respondents assessments of (quality of the process) are presented in Appendix-C. The most five categories considered as customers in construction project were the facilitate quicker and better monitoring, Emphasis on safety regulations, Awareness of the prevailing legislation or laws which may limit the progress of building, A proper understanding of the customers, their financial positions, and Availability or procurement of the right materials of high quality and in the required quantity .

Finally, the result of the 4-point Likert scale scores and the calculated Importance Weight (IW) scores based on respondents assessments of (experiences) are presented in Appendix-D. The most five categories considered such as quality of overall service level, skill of supplier's workers, management and implementation of agreed quality assurance procedures and management of work safety on site

\section{CASE STUDY DEMONSTRATION}

In this paper, a case study of Building Construction Company in Libya was selected to demonstrate the factors affecting customer's satisfaction. The company was founded in 2000. It is dealing with various construction projects which had completed 23 projects with total budget $£ 60$ million. According to company policy regarding customer satisfaction, $65 \%$ of construction projects services delivered on time, within budget and at quality. It is known as one of leaders in the construction industry and enterprises field of Libya. It has record of continuously growing. The company is offering services in electrical, mechanical, concrete production and cement bricks, asphalt steel, carpentry, masonry and exterior finishes. The company established strong relationships with all constructions organization including government and non-government agency who have realized the most of their projects throughout Libya. The company staff consists of professionals, multilingual and hard workings.

The implementation of the main strategy is to select solutions to compare the result which also contains an element of continuous improvement. The operational strategy of company is to involve customer at first in making policy at all operations that may require for improvement. This also includes getting a commitment from all levels of management and staff in the organization to implement the improvement scheme, monitoring the application and development continuously for improvement, renovation and modernization of methods.

This interdependence strengthens the relationship between the consumer and the organization. It also includes the part of the environment of the organization of technology and competition. It is not enough work improvements, if competitors are conducting improvements at a faster rate. Therefore, the company started for continuous improvements for customer satisfaction factors on an ongoing basis to ensure the survival and the sustainability of the organization.

\section{CONCLUSIONS}

The research presented in the paper has focused on analyzing the customer satisfaction factors that influence the quality of product in the construction industry. It was concluded that customer satisfaction can be seen either as a goal or as a measurement tool in the development of the quality of construction process. Versatile analysis was conducted to deepen the understanding of this project success factor which has been stated to be underresearched so far. A number of analyses were made in order to get information about the concept of customer satisfaction as such and different features. Based on the literature and industry review, a framework of interrelationships between customer satisfaction and quality at project level was developed using the findings from the literature review and the characteristics of construction quality.

In the study, a total of fifty five customer satisfaction factors, considered most common in building construction, were listed from literature to rank them using the importance weight (IW) of each factor and frequency index methods. These factors were classified into four subcategories related to expectations and 
adjusted goals of the company, quality of the building construction, quality of the process and experiences. The survey results found that the rank levels of each factor were different from the views of four subcategories. A case study was demonstrated to evaluate the functions of the framework that defines the interrelationship between customer satisfaction and quality at project level. Results showed that the main factors were equally important effect on customer satisfaction from the point of views of the organization product and service. It was concluded that the key customer satisfaction factors were meeting deadline of delivery, organization image, technical support and maintenance, external appearance of the building, safety of the building (protection against crime), location of the building, quality of used labour, allocated space and quality of the electrical service.

The outcome of study is expect to assist policymakers, decision makers and other stakeholders within the construction industry to gain a deep understanding of the construction industry product delivery, enabling them to make efficient decisions to formulate short and long-term construction strategies and policies aiming to improve the industry's processes and operations of quality product delivery.

\section{REFERENCES}

[1] S. Karna, "Analysing customer satisfaction and quality in construction - the case of public and private customers", Nordic Journal of Surveying and Real Estate Research, Special Series, vol. 2, pp. 67-80, 2004.

[2] Z. Torbica, R. Stroh, "HOMBSAT-an instrument for measuring home-buyer satisfaction", Quality Management Journal, vol. 7, no. 4, pp. 32-44, 2001.

[3] W.F. Maloney, "Construction product/service and customer satisfaction", Journal of Construction Engineering and Management, vol. 128, no. 6, pp.522-529, 2002

[4] F. Yasamis, D. Arditi, J. Mohammadi, "Assessing contractor quality performance", Construction Management and Economics, vol. 20, no. 3, pp.211-223, 2002.

[5] C.T. Formoso, M.S.S. Jobim, "Challenges in Improving Customer Focus in small-Sized House-building Companies in Brazil", Journal of Construction in Developing Countries, vol. 11, no. 2, pp. 77-101, 2006.

[6] J. Barlow, R. Ozaki, "User needs customization and new technology in UK housing", European Network on Housing Research Conference, Gavis, Sweden, 2000.

[7] R. Roy, S. Cochrane, "Development of a customer focused strategy in speculative house-building", Construction Management and Economics, vol. 17, no. 6, pp. 777-787, 1999.

[8] O. Shen, Q. Dong, "A structural analysis of Hong Kong's housing sector in the aftermath of the Asian financial turmoil", International Journal of Construction Marketing, vol. 2, no. 1, pp. $1-11,2000$.

[9] D. Gann, "Construction as a manufacturing process, Similarities and differences between industrialized housing and car production in Japan", Construction Management and Economics, vol. 14, no. 5, pp. 437-450, 1996.

[10] G. Ofori, "Globalization and construction industry development: research opportunities", Construction Management and Economics, vol. 18, no. 3, pp. 257-262, 2000.

[11] D.H. Besterfield, "Quality Control", Prentice Hall, Englewood Cliffs, NJ, 1994.

[12] J.D. Barsky, "World-Class Customer Satisfaction", Irwin Professional, Burr Ridge, IL, 1995.

[13] G. Kanji, P. Moura, "Kanji's Business Scorecard”, Total Quality Management, vol. 13, no. 1, pp. 13-27, 2002.
[14] I. Fecikova, "An Index Method for Measurement of Customer Satisfaction," The TQM Magazine, vol. 16, no. 1, pp. 57-66, 2004.

[15] P.E. Love, J. Smith, G.J. Treloarand, H. Li, "Some empirical observations of service quality in construction", Engineering Construction and Architectural Management, vol. 7, no. 2, pp. 191-201, 2000

[16] G. Macintosh, "Customer orientation, relationship quality, and relational benefits to the firm", Journal of Services Marketing, vol. 21, no. 3, pp. 150-159. 2007.

[17] S. Kärnä, "Concepts and attributes of customer satisfaction in construction", TKK Structural Engineering and Building Technology Dissertations, Helsinki University of Technology, Finland, 2009.

[18] Construction Industry Institute (CII), “Total Quality Management: The competitive edge", CII, Austin, TX, USA, 1990.

[19] P. Barrett, "Systems and relationships for construction quality", International Journal of Quality \& Reliability Management, vol. 17, no. 4/5, pp. 377-392, 2000.

[20] Z. Torbica, R. Stroh, "Customer Satisfaction in Home Building", Journal of Construction Engineering and Management, vol. 127, no. 1, pp.82-86, 2001.

[21] A.H. Al-Momani, "Examining service quality within construction processes", Technovation, vol. 20, no. 11, pp. 643-651, 2000.

[22] P. Kotler, "Marketing Management", the Millennium Edition ( $10^{\text {th }}$ ed.), Prentice Hall International, Inc., 2000.

[23] T.O. Jones, W.E. Sasser, "Why Satisfied Customers Defect", Harvard Business Review, vol. 73, no. 6, pp. 88-99, 1995.

[24] C. Brockmann, "Modeling Customer Satisfaction for the AEC Industry", AACE International Transactions, 2002.

[25] P.E. Love, J. Smith, G.J. Treloar, H. Li, "Some empirical observations of service quality in construction", Engineering Construction and Architectural Management, vol. 7, no. 2, pp. 191-201, 2000.

[26] C. Homburg, B. Rudolph, "Customer Satisfaction in Industrial Markets: dimensional and multiple role issues", Journal of Business Research, vol. 52, no. 1, pp. 15-33, 2000

[27] S.T. Kometa, P.O. Olomolaiye, F.C. Harris, "Attributes of UK Construction Clients Influencing Project Consultants' Performance", Construction Management and Economics, vol. 12, no. 5, pp. 433-443, 1994.

[28] C. Lin, W. Chow, C. Madu, C-H. Kueiand, P. Yu, "A structural equation model of supply chain quality management and organizational performance", International Journal of Production Economics, vol. 96, no. 3, pp.355-365, 2005.

[29] L.K. Molinari, R. Abratt, P. Dion, "Satisfaction, quality and effects on repurchase and positive word-of-mouth behavioural intentions in a B2B services context", Journal of Services Marketing, vol. 22, no. 5, pp. 363-373, 2008.

[30] M. Ball, M. Grilli, "Housing Markets and Economic Convergence in the European Union", Royal Institution of Chartered Surveyors, London, UK, 1997.

[31] E. Chinyo, P.O. Olomolaiye, P. Corbett, "Quantification of Construction Clients Needs Through Paired Comparisons", Journal of Management in Engineering, vol. 14, no. 1, pp. 87-92, 1998.

[32] M. Egemen, A.N. Mohamed, "Clients' needs, wants and expectations from contractors and approach to the concept of repetitive works in the Northern Cyprus construction market", Building and Environment, vol. 41, no. 5, pp. 602-614, 2005.

[33] T.J. Holt, D.R. Jones, S.J. Hawkins, R.G. Hartnoll, "The Sensitivity of Marine Communities to Man-induced Change: A Scoping Report", Contract Science Report, No. 65, Countryside Council for Wales, 1995.

[34] A. Wa'el, R.A. Mohd, A.S. Kadir, D. Ernawati, "The significant factors causing delay of building construction projects in Malaysia", Engineering, Construction and Architectural Management, vol. 14, no. 2, pp. 192-206, 2007.

[35] S.M. Ahmed, R. Kangari, "Analysis of Client-Satisfaction Factors in Construction Industry", Journal of Management in Engineering, vol. 11, no. 2, pp. 36-42, 1995.

[36] E.W. Anderson, M.W. Sullivan, "The Antecedents and Consequences of Customer Satisfaction for Firms", Marketing Science, vol. 12, no. 2, pp. 125-143, 1993. 
APPENDIX

APPENDIX - 1: IMPORTANCE WEIGHT AND RANKING SCALE OF THE COMPANY GOALS

\begin{tabular}{|c|c|c|c|c|c|c|c|}
\hline \multirow{2}{*}{$\begin{array}{c}\text { S } \\
\text { /No. }\end{array}$} & \multirow{2}{*}{ Expectations and adjusted goals of the Company } & \multicolumn{2}{|c|}{ Disagree } & \multicolumn{2}{|c|}{ Strongly agree } & \multirow{2}{*}{ IW } & \multirow{2}{*}{ Rank } \\
\hline & & & & & & & \\
\hline 1 & Friendliness & 12 & 10 & 13 & 8 & 59.88 & 1 \\
\hline 2 & Delivered aconstruction projects on time, within budget and at quality & 14 & 12 & 11 & 6 & 55.23 & 2 \\
\hline 3 & $\begin{array}{l}\text { Availability or procurement of the right materials of high quality and in the re } \\
\text { quired quantity }\end{array}$ & 20 & 13 & 6 & 4 & 46.51 & 3 \\
\hline 4 & $\begin{array}{l}\text { Appointment of a competent Project manager and also a support management } \\
\text { team }\end{array}$ & 23 & 13 & 4 & 3 & 42.44 & 4 \\
\hline 5 & The company's previous reputation and building project records & 25 & 12 & 3 & 3 & 40.69 & 5 \\
\hline 6 & $\begin{array}{l}\text { Possession of the right tools and equipment in desired quantity and quality by } \\
\text { the company. }\end{array}$ & 29 & 14 & 0 & 0 & 33.13 & 6 \\
\hline
\end{tabular}

APPENDIX - 2: IMPORTANCE WEIGHT AND RANKING SCALE OF THE QUALITY OF THE BUILDING

\begin{tabular}{|c|c|c|c|c|c|c|c|}
\hline $\mathbf{S}$ & & \multicolumn{2}{|c|}{ Disagree } & \multicolumn{2}{|c|}{ Strongly agree } & IYY & \\
\hline $\mathbf{A}$ & PERFORMANCE OF BUILDING AS A WHOLE & & & & & & \\
\hline 1 & Performance of facades & 12 & 11 & 10 & 10 & 60.46 & 1 \\
\hline 2 & Adequacy of the communal areas & 14 & 12 & 9 & 8 & 56.39 & 2 \\
\hline 3 & Location of the building & 16 & 11 & 9 & 7 & 54.06 & 3 \\
\hline 4 & Safety of the building (protection against crime) & 16 & 12 & 9 & 6 & 52.9 & 4 \\
\hline 5 & External appearance of the building & 19 & 13 & 8 & 3 & 47.09 & 5 \\
\hline B & PERFORMANCE OF THE APPARTMENT & & & & & & \\
\hline 1 & Adequacy of space to furniture and to programmed activities & & & & & & \\
\hline 1.1 & Bathrooms & 9 & 13 & 11 & 10 & 62.79 & 1 \\
\hline 1.2 & Living room & 12 & 12 & 10 & 9 & 59.3 & 2 \\
\hline 1.3 & Kitchen and laundry rooms & 18 & 13 & 8 & 4 & 48.83 & 3 \\
\hline 1.4 & Bedrooms & 23 & 10 & 8 & 2 & 43.60 & 4 \\
\hline 1.5 & Maximal use of allocated space & 25 & 13 & 5 & 0 & 0.38 & 5 \\
\hline 2 & Natural conditions of comfort & & & & & & \\
\hline 2.1 & Winter internal temperature & 11 & 10 & 10 & 12 & 63.37 & 1 \\
\hline 2.2 & Summer internal temperature & 14 & 10 & 9 & 10 & 58.72 & 2 \\
\hline 2.3 & Acoustics & 18 & 11 & 8 & 6 & 51.16 & 3 \\
\hline 2.4 & Lighting & 21 & 12 & 7 & 3 & 45.34 & 4 \\
\hline 3 & Electrical services & & & & & & \\
\hline 3.1 & Number and location of plugs and bulbs & 11 & 15 & 8 & 9 & 58.72 & 1 \\
\hline 3.2 & Quality of the service & 16 & 14 & 9 & 4 & 50.58 & 2 \\
\hline 4 & Water service & & & & & & \\
\hline 4.1 & Quality of the service & 9 & 13 & 10 & 11 & 63.37 & 1 \\
\hline 4.2 & Quantity and location of the services & 14 & 13 & 9 & 7 & 55.23 & 2 \\
\hline 5 & Quality of the finishing & & & & & & \\
\hline 5.1 & Ceramic tiles & 9 & 11 & 10 & 13 & 65.69 & 1 \\
\hline 5.2 & Floor finishing & 12 & 11 & 10 & 10 & 60.46 & 2 \\
\hline 5.3 & Bathrooms and appliances & 15 & 12 & 7 & 9 & 55.81 & 3 \\
\hline 5.4 & Quality of doors, windows and roofing materials & 20 & 17 & 2 & 4 & 44.18 & 4 \\
\hline 5.5 & Locks & 23 & 19 & 1 & 0 & 37.20 & 5 \\
\hline 5.6 & Quality of labour used & 26 & 17 & 0 & 0 & 34.88 & 6 \\
\hline
\end{tabular}


APPENDIX - 3: IMPORTANCE WEIGHT AND RANKING SCALE OF QUALITY OF THE PROCESS

\begin{tabular}{|c|c|c|c|c|c|c|c|}
\hline $\begin{array}{c}\text { S } \\
\text { No. }\end{array}$ & Quality of the process & \multicolumn{4}{|c|}{ Strongly agree } & IW & Rank \\
\hline 1 & Delegation of authority to facilitate quicker and better monitoring & 8 & 14 & 13 & 8 & 62.2 & 1 \\
\hline 2 & Emphasis on safety regulations and sanctioning offenders & 11 & 14 & 10 & 8 & 58.72 & 2 \\
\hline 3 & $\begin{array}{l}\text { Awareness of the prevailing legislation or laws which may limit the progress } \\
\text { of building }\end{array}$ & 16 & 15 & 11 & 1 & 48.25 & 3 \\
\hline 4 & $\begin{array}{l}\text { A proper understanding of the customers, their financial positions, their } \\
\text { expectations }\end{array}$ & 17 & 13 & 12 & 1 & 47.25 & 4 \\
\hline 5 & $\begin{array}{l}\text { Availability or procurement of the right materials of high quality and in the } \\
\text { required quantity }\end{array}$ & 19 & 15 & 6 & 3 & 45.34 & 5 \\
\hline 6 & Ability to mobilize personnel and materials to site at the shortest notice & 21 & 13 & 9 & 0 & 43.02 & 21 \\
\hline 7 & Experiences and competences of the employees of the company & 20 & 17 & 5 & 1 & 42.44 & 7 \\
\hline 8 & Allocation of enough time for regular meetings to enable receipt of feed back & 23 & 17 & 3 & 0 & 38.37 & 8 \\
\hline 9 & Constant consultations with the owner to ensure smooth progress & 24 & 18 & 1 & 0 & 36.62 & 9 \\
\hline 10 & Proper understanding of the legal framework of contractual agreements & 26 & 15 & 2 & 0 & 36.04 & 10 \\
\hline 11 & Recruitment of competent work team who are adequately motivated & 28 & 15 & 0 & 0 & 33.72 & 11 \\
\hline 12 & $\begin{array}{l}\text { Appointment of a competent Project manager and also a support management } \\
\text { team }\end{array}$ & 30 & 13 & 0 & 0 & 32.55 & 12 \\
\hline 13 & $\begin{array}{l}\text { Possession of the right tools and equipment in desired quantity and quality by } \\
\text { the company }\end{array}$ & 32 & 11 & 0 & 0 & 31.39 & 13 \\
\hline 14 & $\begin{array}{l}\text { The Company's tender procedure, including costs, project duration, designs } \\
\text { and other details }\end{array}$ & 34 & 8 & 1 & 0 & 30.81 & 14 \\
\hline 15 & The company's previous reputation and building project records & 37 & 4 & 1 & 1 & 30.23 & 15 \\
\hline
\end{tabular}

APPENDIX - 4: IMPORTANCE WEIGHT AND RANKING SCALE OF EXPERIENCES

\begin{tabular}{|c|c|c|c|c|c|c|c|}
\hline $\mathbf{S}$ & Exneriences & \multicolumn{4}{|c|}{ Strongly agree } & IU & Rank \\
\hline 1 & Contracted work quality & 14 & 11 & 10 & 8 & 56.97 & 1 \\
\hline 2 & Management and implementation of agreed quality assurance procedures & 16 & 11 & 8 & 8 & 54.65 & 2 \\
\hline 3 & Quality of overall service level & 19 & 11 & 7 & 6 & 50.02 & 3 \\
\hline 4 & Management of work safety on site & 21 & 10 & 7 & 5 & 47.67 & 4 \\
\hline 5 & Quality of assignment material and maintenance manual & 22 & 11 & 6 & 4 & 45.34 & 5 \\
\hline 6 & Skill of supplier's workers & 24 & 13 & 4 & 2 & 40.69 & 6 \\
\hline 7 & All other companies involved in building construction & 25 & 14 & 3 & 1 & 38.37 & 7 \\
\hline 8 & All sub-contractors and suppliers of materials to your company & 26 & 16 & 1 & 0 & 35.46 & 8 \\
\hline 9 & Government regulatory agencies who certify buildings & 28 & 14 & 1 & 0 & 34.30 & 9 \\
\hline 10 & Agreement about changes & 30 & 13 & 0 & 0 & 32.55 & 10 \\
\hline
\end{tabular}

